Artículo científico

Volumen 31(3):695-707. Septiembre-diciembre, 2020 e-ISSN 2215-3608, doi:10.15517/am.v31i3.40892 http://www.revistas.ucr.ac.cr/index.php/agromeso

\title{
Quality of raw milk in the highland tropics of Nariño, Colombia ${ }^{1}$
}

\section{Calidad de la leche cruda en el trópico alto de Nariño, Colombia}

\author{
Magaly Elizabeth Tobar-Delgado², José Luis Rodríguez-Bautista ${ }^{3}$,Rocio Esperanza Patiño-Burbano ${ }^{4}$, Francisco \\ Emilio Argote-Vega ${ }^{5}$, Edwin Castro-Rincón ${ }^{6}$, Henry David Mogollón-García ${ }^{7}$
}

1 Reception: March 4, 2020. Acceptance: June 17, 2020. This study was part of a project carried out by Corporacion Colombiana de Investigación Agropecuaria (AGROSAVIA) with resources from General Royalties System, Colombia.

2 Universidad Nacional de Colombia, Departamento de Procesos Agroindustriales, Cra. 32 \# 12- 00 Palmira, Valle del Cauca, Colombia. elizabetth.t93@gmail.co (https://orcid.org/0000-0001-9920-4094).

3 Universidad Federal Rural de Rio de Janeiro, Programa de Post grado, Seropédica, Rio de Janeiro, Brazil. jlrodriguezb@yahoo.com (https:// orcid.org/0000-0002-9407-171X).

4 Corporación Colombiana de Investigación Agropecuaria (AGROSAVIA). Centro de Investigación Tibaitatá, Km 14 Mosquera-Bogotá, Cundinamarca, Colombia. rpatino@agrosavia.co (http://orcid.org/0000-0003-2970-9876).

5 TEA Research Group, Universidad de Nariño, Calle 18, Carrera 50, ciudadela universitaria Torobajo, Pasto, Nariño, Colombia. argote_71@ hotmail.com (https://orcid.org/0000-0003-4024-423X).

6 Corporación Colombiana de Investigación Agropecuaria (AGROSAVIA). Centro de Investigación Tibaitatá, Km 14 Mosquera-Bogotá, Cundinamarca, Colombia. ecastro@agrosavia.co (https://orcid.org/0000-0001-9841-8242).

7 Universidad Estadual Paulista “Júlio de Mesquita Filho”, Facultad de Medicina Veterinaria y Zootecnia, Departamento de Radiología Animal y Reproducción Animal, Botucatu, Sao Paulo, Brazil (corresponding author mogollongarcia@hotmail.com; https://orcid.org/0000-00030820-5847).

\begin{abstract}
Introduction. The production and commercialization of raw milk in Nariño, Colombia, follows microbiological and compositional standards on which payment for quality is made. However, quality can be affected during its transport after milking. Objective. To describe the microbiological and compositional quality of raw milk in the highland tropic. Materials and methods. The study was carried out in seven municipalities in the department of Nariño, Colombia, during the rainy season between February and July of 2017. Two milk samples from the same milk can were collected, one after milking ( $f a r m ; n=10)$, and the second at the collection point (tank; $n=10$ ). In each sample, the following variables were evaluated: height above the sea level of the collection site, aerobic mesophilic count (CFU), total coliform count (COL), milk temperature, fat (FAT), protein (PC) and total solids (TS). Results. The temperature of the milk was higher on the farm compared to the tank ( $30 \pm 0.68$ vs. $23 \pm 0.87{ }^{\circ} \mathrm{C}$, respectively).

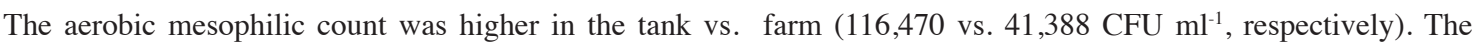
temperature of the milk was negatively correlated with the distance and the transport time of the milk $(-0.86$ and -0.84 , respectively). The compositional quality of the milk was not affected by transport conditions. Conclusion. In the high tropic conditions, the microbiological quality of raw milk was negatively affected by the increase in the aerobic mesophilic counts.
\end{abstract}

Keywords: fat, aerobic mesophilic, microbiological, protein, total solids. 


\section{Resumen}

Introducción. La producción y comercialización de leche cruda en Nariño, Colombia, se rige bajo estándares microbiológicos y composicionales sobre los cuales se efectúa el pago por calidad. Sin embargo, la calidad se puede ver afectada debido al transporte posterior al ordeño. Objetivo. Describir la calidad microbiológica y composicional de la leche cruda en el trópico alto. Materiales y métodos. El estudio fue realizado en siete municipios del departamento de Nariño, Colombia, durante la temporada de lluvias comprendida entre los meses de febrero a julio del año 2017. Se recolectaron dos muestras de leche de la misma lata de leche, una después del ordeño (granja; $n=$ 10), y la segunda en el punto de recogida (tanque; $n=10$ ). En cada muestra se evaluaron las siguientes variables: altura sobre el nivel del mar del lugar de colecta, conteo de mesófilos aerobios (UFC), conteo de coliformes totales (COL), temperatura de la leche, grasa (GR), proteína (PR) y sólidos totales (ST). Resultados. La temperatura de la leche fue mayor en la finca comparada con el tanque ( $30 \pm 0,68$ vs. $23 \pm 0,87^{\circ} \mathrm{C}$, respectivamente). El recuento de mesófilos aerobios fue mayor en el tanque vs. finca (116,470 vs. 41,388 CFU ml-1 , respectivamente). La temperatura de la leche fue correlacionada negativamente con la distancia y el tiempo de transporte de la leche $(-0,86$ y $-0,84$, respectivamente). La calidad composicional de la leche no la afectó las condiciones de transporte. Conclusión. En las condiciones del trópico alto, la calidad microbiológica de la leche cruda estuvo afectada de manera negativa por el aumento en el recuento de mesófilos aerobios.

Palabras clave: grasa, mesófilos aerobios, microbiológicos, proteína, sólidos totales.

\section{Introduction}

Within current consumer trends, quality and food safety are a priority to meet product characteristics and consumer needs (Hammond et al., 2015; Murphy et al., 2016). One of the highest demanded perishable food products worldwide is milk. In 2019, milk global production increase $1.4 \%$, in total 852 million tonnes were reported (FAO, 2020); in 2019 Colombia reached 7,300 t (FEDEGAN, 2019). Milk contains water, nutrients, minerals, and it is close to neutral $\mathrm{pH}$. These characteristics make it a highly susceptible product to deterioration by the action of natural enzymes and contaminating microorganisms derived from the udder, or even crosscontamination after milking (Vithanage et al., 2016).

Facultative aerobic microorganisms are described as the main contaminants of milk, including within this group, bacteria of the Bacillus genus; these are responsible for the fermentation of glucose and reducing the $\mathrm{pH}$, generating acidification, coagulation, and proteolysis due to the enzymatic action (Barbaros, 1999). At the same time, milk quality and its derivatives can be modified by the action of total coliforms from environmental pollution, which grow exponentially with generation time and duplication as early as $30 \mathrm{~min}$ on temperatures above $25^{\circ} \mathrm{C}$, a particularity related to being facultative aerobes (Pantoja et al., 2011).

Contamination and deterioration of the microbiological quality of milk can occur throughout the entire production chain; however, traceability studies (Swai and Schoonman, 2011; Paszkiewicz et al., 2015; Tolosa et al., 2016) have shown that the bacterial contamination and proliferation in milk is mainly due to the poor conservation and storage conditions once milking is finished.

A study related the conditions of post-milking handling with the changes in the quality of raw milk once it was delivered to the collection points. Probably these physical and chemical alterations occurred because the temperature changes associated with the effect of the external environment, geographical location, or seasonality (Leal, 2017). To preserve milk quality is necessary keep a good refrigeration system, decreasing the temperature to at least $10{ }^{\circ} \mathrm{C}$ or $4{ }^{\circ} \mathrm{C}$ within 2 or $4 \mathrm{~h}$ after milking, respectively (WHO and FAO, 2011; FAO, 2015). 
The transport of perishable food was governed under strict legislation and cold chain implementation systems, which are controlled by health surveillance authorities according to the environmental requirements of each country (Perko, 2011). In countries with high production volumes, milk collection was carried out in robust vehicles, equipped with several compartments that conserve food and simultaneously avoid mixing milk from different producers, following a rigorous logistics and technological structuring process (Butler et al., 2005; Caramia and Guerriero, 2009; Claassen and Hendriks, 2007; Masson et al., 2015).

In climatic conditions of lowland tropical areas or regions with a warm summer, finding microbiological counts in raw milk has been highlighted, emphasizing points, such as the time the milk remains in the herd after milking, and the distance and time elapsed until reaching the reception points. The environmental temperature together with the absence of cooling systems in these areas allows the rapid growth of contaminating microorganisms such as mesophilic bacteria (Ruiz-Cortés et al., 2012).

In a recent study was observed that in small dairy farms, the quality of raw milk was affected by inadequate transport conditions (De-Silva et al., 2016). Additionally, high counts in the number of coliform microorganisms and moderate variations in milk temperature were reported (Fatouma-Mohamed-Latif et al., 2017). Another factor with negative effect is the season. Recent studies showed an increase in microbiological counts in dry season (Álvarez-Fuentes et al., 2012; Martínez and Gomez, 2013). In another study, adverse results were observed; in this case, higher microbiological counts were observed on rainy season (Calderon et al., 2006). Furthermore, in a field study carried out along the milk chain with inadequate conditions of transport, revealed that microbiological counts were higher in rainy than dry season (Millogo et al., 2010).

Similar to other countries, the dairy industry in Colombia considers sanitary and compositional hygienic quality as acceptance parameters for processing and commercialization; likewise, the regulations sectorize the regions into two groups according to their geographical conditions. The study area of the current research belongs to region 1, which corresponds to a highland tropical area; similarly, the total bacterial counts must be minimal, free of pathogenic microorganisms, and meet the criteria of percentage of fat, protein and total solids (Resolución 000017, Ministerio de Agricultura, 2012).

However, in the department of Nariño, Colombia, dairy farming was carried out in small and medium-sized livestock farms that do not have refrigeration systems for the milk. In each farm, milk cooling was performed by milk can immersion in water wells. At the same day, milk was moved to community storage tank where it was collected by transport. This artisanal cooling system takes advantage of the climatic conditions of the region that is located close to 3,000 meters above sea level. Accordingly, the aim of this study was to describe the microbiological and compositional quality of raw milk in the highland tropics.

\section{Materials and methods}

\section{Farm selection}

The study was carried out in ten farms located in the department of Nariño, Colombia, belonging to the municipalities of Yaramal, Cuaspud Carlosama, Guachucal, Pupiales, Tuquerres, and Buesaco. The study was conducted out jointly with six producer associations. Farm selection was made considering milk volume production, type of milking, distance to the collection point or production plant, collection route, and transport means used (Table 1). The data of total milk production was reported in Consolidado agropecuario de Nariño 2016 (Secretaría de Agricultura y Medio Ambiente de Nariño, 2016). 
Table 1. Data relation of total milk production, milking type, and transport with the locality where the sampling was carried out. Nariño, Colombia, 2017.

Cuadro 1. Relación de datos de producción total de leche, tipo de ordeño y transporte con la localidad donde se realizó el muestreo. Nariño, Colombia, 2017.

\begin{tabular}{cccc}
\hline Locality (Municipality) & Total milk production $(\mathbf{l})$ & Milking type & Transport type \\
\hline Yaramal & 56,267 & Manual, mechanical & Motorcycle, truck \\
Cuaspud Carlosama & 37,438 & Manual, mechanical & Beasts of burden \\
Guachucal & 129,543 & Manual, mechanical & Motorcycle, truck \\
Pupiales & 95,841 & Manual, mechanical & Motorcycle, truck \\
Tuquerres & 77,000 & Manual, mechanical & Motorcycle, truck \\
Buesaco & 11,732 & Manual & Beasts of burden \\
\hline
\end{tabular}

\section{Milk sampling}

Milk samples (Holstein cattle) were collected during the rainy season between February and July 2017. Before each collection, information was obtained related to the type of milking employed. Sampling was carried out following the guidelines on how to take raw milk samples for the Corpolac laboratory. To analyses microbiological and compositional quality of raw milk changes, for each farm, two milk samples from the same milk can were collected. The first sample was collected after morning milking (farm; $n=10$ ), at the same day, the second sample was collected once the milk can was located at the community collection point (tank; $n=10)$. The milk in the milk can came from one or more cows. For both the farm and the tank groups, once the questionnaire was completed, milk temperature in the can or canteen was measured using a thermometer (Century Harvest; model LE-MT-001); besides, after homogenization, $240 \mathrm{ml}$ of milk was collected and divided into four sterile flasks each with a capacity of $60 \mathrm{ml}$. Furthermore, an additional bottle to take a temperature control measurement was collected. Once this was carried out, samples were packed in refrigerators and sent under cold chain conditions to the milk laboratories of the research centers of Corporacion Colombiana de Investigacion Agropecuaria (AGROSAVIA) in Obonuco, state of Nariño, and Tibaitata in the state of Cundinamarca to analyze the contents of fat, protein, total solids, and microbiological quality, respectively. The samples were processed within 24 hours after collection.

\section{Collection of geographic data and time}

Geographic data such as latitude, longitude, altitude, environmental temperature, and distance were established both on-farm and in the tank (collection center) using a global positioning system (GPS, Garmin, 64s) (Table 2). Milk travel time from the farm until reaching the collection point was calculated using a laboratory timer (Kitchen timer, JS-118).

\section{Sanitary and microbiological analyses}

The presence of aerobic mesophilic bacteria (CFU) and total coliforms (COL) were carried out using the BactoScan (Norma ISO NTCISO9001) (Centro América S.A. de C.V., Mexico) equipment that employs the flow cytometry method, and the quantification of COL employed Petrifilm plates. Once the milk samples entered the laboratory, the cold chain was confirmed by measuring the temperature in a control milk sample that was taken from 
Table 2. Results discriminated by farm and sampling point for the variables: raw milk temperature, time, and travel distance from the farm to the collection tank, height above the sea level, and environmental temperature. Nariño, Colombia, 2017.

Cuadro 2. Resultados discriminados por finca y punto de colecta para las variables: temperatura de la leche cruda, tiempo y distancia desde la finca hasta el tanque de almacenamiento, altura sobre el nivel del mar y temperatura ambiental. Nariño, Colombia, 2017.

\begin{tabular}{|c|c|c|c|c|c|c|}
\hline Farm & Collection point & $\begin{array}{l}\text { Milk temperature } \\
\left({ }^{\circ} \mathrm{C}\right)\end{array}$ & Time (min) & Distance (km) & $\begin{array}{l}\text { Altitude } \\
\text { (m.a.s.l.) }\end{array}$ & $\begin{array}{l}\text { Environmental } \\
\text { temperature }\left({ }^{\circ} \mathbf{C}\right)\end{array}$ \\
\hline \multirow[t]{2}{*}{1} & Farm & 30.2 & 15 & 6.6 & 3,101 & 11.2 \\
\hline & Tank & 27.5 & & & 3,095 & \\
\hline \multirow[t]{2}{*}{2} & Farm & 36.3 & 63 & 9.3 & 2,943 & 10.4 \\
\hline & Tank & 23.9 & & & 3,033 & \\
\hline \multirow[t]{2}{*}{3} & Farm & 30.7 & 40 & 12.6 & 3,166 & 9.8 \\
\hline & Tank & 24.8 & & & 3,185 & \\
\hline \multirow[t]{2}{*}{4} & Farm & 28.2 & 35 & 8.0 & 3,166 & 10.2 \\
\hline & Tank & 23.5 & & & 3,185 & \\
\hline \multirow[t]{2}{*}{5} & Farm & 32.5 & 210 & 19.6 & 3,111 & 11.4 \\
\hline & Tank & 24.5 & & & 3,118 & \\
\hline \multirow[t]{2}{*}{6} & Farm & 27.3 & 226 & 17.2 & 3,112 & 11.2 \\
\hline & Tank & 21.6 & & & 3,118 & \\
\hline \multirow[t]{2}{*}{7} & Farm & 27.5 & 208 & 21.6 & 3,116 & 9.9 \\
\hline & Tank & 19.9 & & & 3,118 & \\
\hline \multirow[t]{2}{*}{8} & Farm & 26.2 & 200 & 22.6 & 3,286 & 9.1 \\
\hline & Tank & 22.9 & & & 3,298 & \\
\hline \multirow[t]{2}{*}{9} & Farm & 25.7 & 190 & 22.6 & 3,283 & 12.1 \\
\hline & Tank & 23.1 & & & 2,398 & \\
\hline \multirow[t]{2}{*}{10} & Farm & 33.0 & 150 & 16.3 & 2,660 & 18.9 \\
\hline & Tank & 19.5 & & & 2,385 & \\
\hline
\end{tabular}

the beginning of the sampling session on the farm. A subsample of $5 \mathrm{ml}$ of milk was taken after homogenization for $3 \mathrm{~min}$ from the $60 \mathrm{ml}$ flask obtained from the original milk sample to quantify aerobic mesophilic microorganisms. This sample was taken to the equipment, and the reading of the total number of bacteria was made after $10 \mathrm{~min}$. Sample treatment, equipment operation, and reagent preparation were carried out following the instructions of the manufacturer.

\section{Compositional analysis}

The contents of fat (FAT), protein (PC), and total solids (TS) were established using the MilkoScan equipment (Centro América S.A. de C.V. México). In a thermostat-controlled bath, $5 \mathrm{ml}$ of the milk samples were collected and homogenized for $3 \mathrm{~min}$ at $39^{\circ} \mathrm{C}$. Sample treatment, as well as equipment operation and reagent preparation, were conducted following the manufacturer's instructions.

\section{Statistical analysis}

There was a fully randomized experiment design. The estimation of normality was made using the ShapiroWilk test, and when it was required, a logarithmic transformation of the data was performed (Lopes et al., 
2012). Parameters CFU and COL were compared using the median and applying the NPAR1WAY procedure that contemplates a nonparametric analysis using Wilcoxon's test; results were presented as median and range considering significant statistical difference when $\mathrm{p}<0.05$.

Spearman's correlation was established to associate milk temperature with distance and transport time employing the Proc CORR procedure. Results were showed as a correlation coefficient.

The comparison of means for the milk temperature, FAT, PC, and TS variables were performed using the paired $\mathrm{t}$-test. Altitude was compared using an unpaired t-test. Results were presented as mean \pm standard error of the mean (SEM), considering significant statistical difference when $\mathrm{p}<0.05$. All the data were analyzed using the statistical package SAS Version 9.4 (SAS Institute Inc., Cary, NC, USA).

\section{Results}

\section{Geographic data and time}

Milk temperature $\left(30.4 \pm 0.68^{\circ} \mathrm{C}\right)$ in the farm was higher $(\mathrm{p}<0.05)$ compared to the temperature observed in the tank $\left(23 \pm 0.87^{\circ} \mathrm{C}\right)$, with a difference of $7{ }^{\circ} \mathrm{C}$ (Table 3).

Table 3. Mean \pm standard error of the mean (SEM) of the variables time, distance, temperature, and height at the location of the raw milk sample collection in the highland tropic. Nariño, Colombia. 2017.

Cuadro 3. Promedio \pm error estándar del promedio (EE) de las variables tiempo, distancia, temperatura y altura en el sitio de colecta de la muestra de la leche cruda en el trópico alto. Nariño, Colombia. 2017.

\begin{tabular}{ccc}
\hline Variable & Farm $(\mathbf{n}=\mathbf{1 0})$ & Tank $(\mathbf{n}=\mathbf{1 0})$ \\
\hline Time $(\mathrm{min})$ & $*$ & $154.6 \pm 30.4$ \\
Distance $(\mathrm{km})$ & $*$ & $15.2 \pm 1.5$ \\
Milk temperature $\left({ }^{\circ} \mathrm{C}\right)$ & $30.4 \pm 0.68^{\mathrm{a}}$ & $23 \pm 0.87^{\mathrm{b}}$ \\
Altitude $(\operatorname{mas})$ & $2,989 \pm 60^{\mathrm{a}}$ & $2,950 \pm 131^{\mathrm{a}}$ \\
\hline
\end{tabular}

$\left.{ }^{(\mathrm{a}-\mathrm{b}}\right)$ Different letters between rows indicate a significant statistical difference $(\mathrm{p}<0.05) /\left({ }^{\mathrm{a}-\mathrm{b}}\right)$ Letras diferentes entre columnas indican diferencias estadísticas significativas $(\mathrm{p}<0,05)$.

* Data equivalent to zero (0)/* Dato equivalente a cero $(0)$.

\section{Microbiological analysis}

The results obtained in this study showed higher aerobic mesophilic bacteria (CFU) counts $(\mathrm{p}<0.05)$ in the tank compared to the ones on the farm (Table 4).

\section{Association between milk temperature with distance and transport time}

Milk temperature showed a strong negative correlation with distance (-0.86) and milk transport time (-0.84) (Figure $1 \mathrm{~A}$ and $1 \mathrm{~B}$, respectively). For both cases, there was a significant statistical difference $(\mathrm{p}<0.0001)$. 
Table 4. Median (upper and lower range) of aerobic mesophilic bacteria (CFU) and total coliforms (COL) in raw milk samples collected on the farm and in the raw milk storage tank in highland tropic. Nariño, Colombia. 2017.

Cuadro 4. Mediana (límite superior e inferior) de bacterias mesófilas aerobias (UFC) y coliformes totales (COL) in muestras de leche colectadas en finca y en el tanque de acopio de la leche cruda, en el trópico alto. Nariño, Colombia. 2017.

\begin{tabular}{cccc}
\hline Parameter & Variable & Farm $(\mathbf{n}=\mathbf{1 0})$ & Tank $(\mathbf{n}=\mathbf{1 0})$ \\
\hline & $\mathrm{CFU} \mathrm{ml}^{-1}$ & $21,680(430,567-1,315)^{\mathrm{b}}$ & $109,432(450,391-1,924)^{\mathrm{a}}$ \\
Microbiological & $\mathrm{COL}\left(\mathrm{CFU} \mathrm{ml}^{-1}\right)$ & $510(6,950-9)^{\mathrm{a}}$ & $217(8,600-5)^{\mathrm{a}}$ \\
\hline
\end{tabular}

$\left.{ }^{(a-b}\right)$ Different letters between rows indicate a significant statistical difference $(\mathrm{p}<0.05) /\left({ }^{\mathrm{a}-\mathrm{b}}\right)$ Letras diferentes entre columnas indican diferencias estadísticas significativas $(\mathrm{p}<0,05)$.

CFU (colony forming units): aerobic mesophiles. / CFU (unidades formadoras de colonias): mesófilos aeróbicos.

COL: total coliforms / COL: coliformes totales.

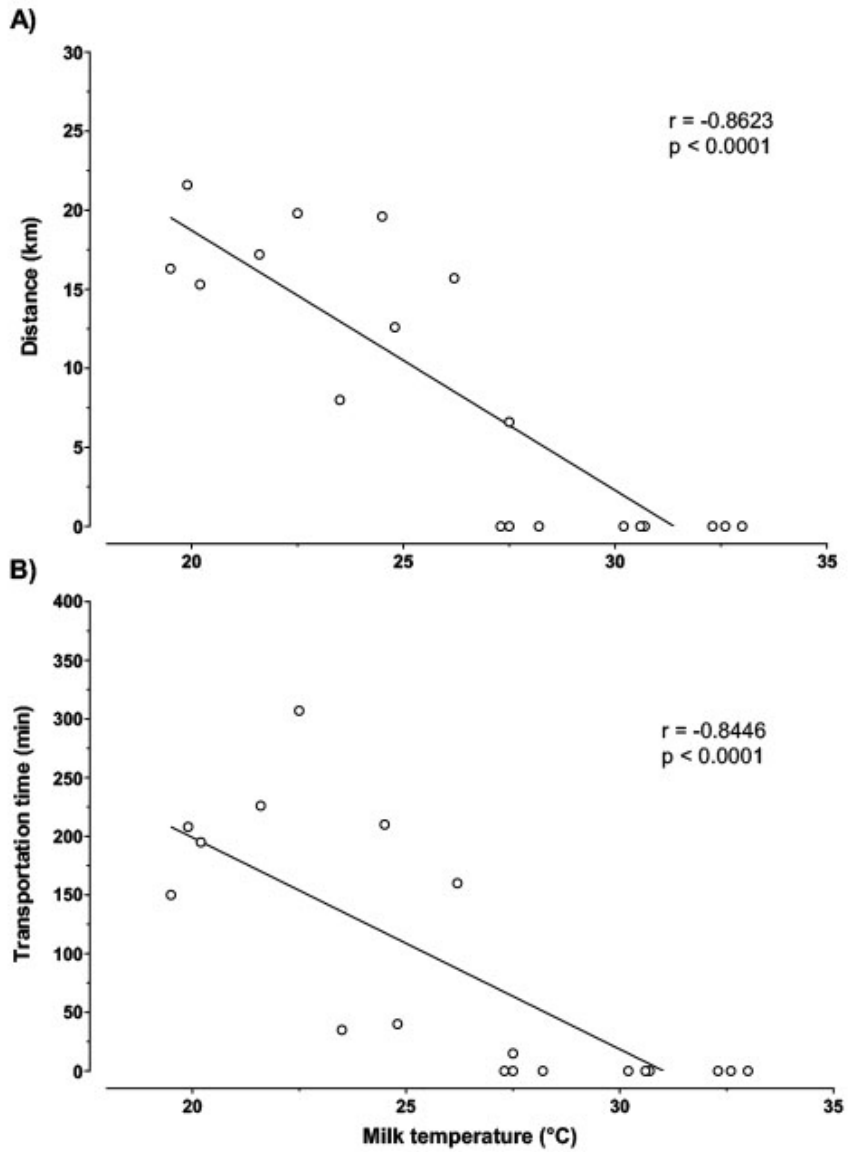

Figure 1. Spearman's correlation between the raw milk temperature and A) the distance from the farm to the tank (collection center), and B) the transport time of the raw milk from the farm to the tank (collection point). The circles indicate individual observations. Nariño, Colombia, 2017.

Figura 1. Correlación de Spearman entre la temperatura de la leche cruda y A) la distancia desde la finca al tanque (centro de acopio), y B) el tiempo de transporte de la leche cruda desde la finca hasta el tanque (centro de acopio). Las observaciones individuales son mostradas como círculos. Nariño, Colombia, 2017. 


\section{Compositional analysis}

No group effect was observed ( $\mathrm{p}>0.05$ ); moreover, statistical differences for FAT, PC, and TS variables (Figure $2 \mathrm{~A}, 2 \mathrm{~B}$, and $2 \mathrm{C}$, respectively) were not observed when comparing the farm with the tank groups ( $\mathrm{p}>0.05)$.
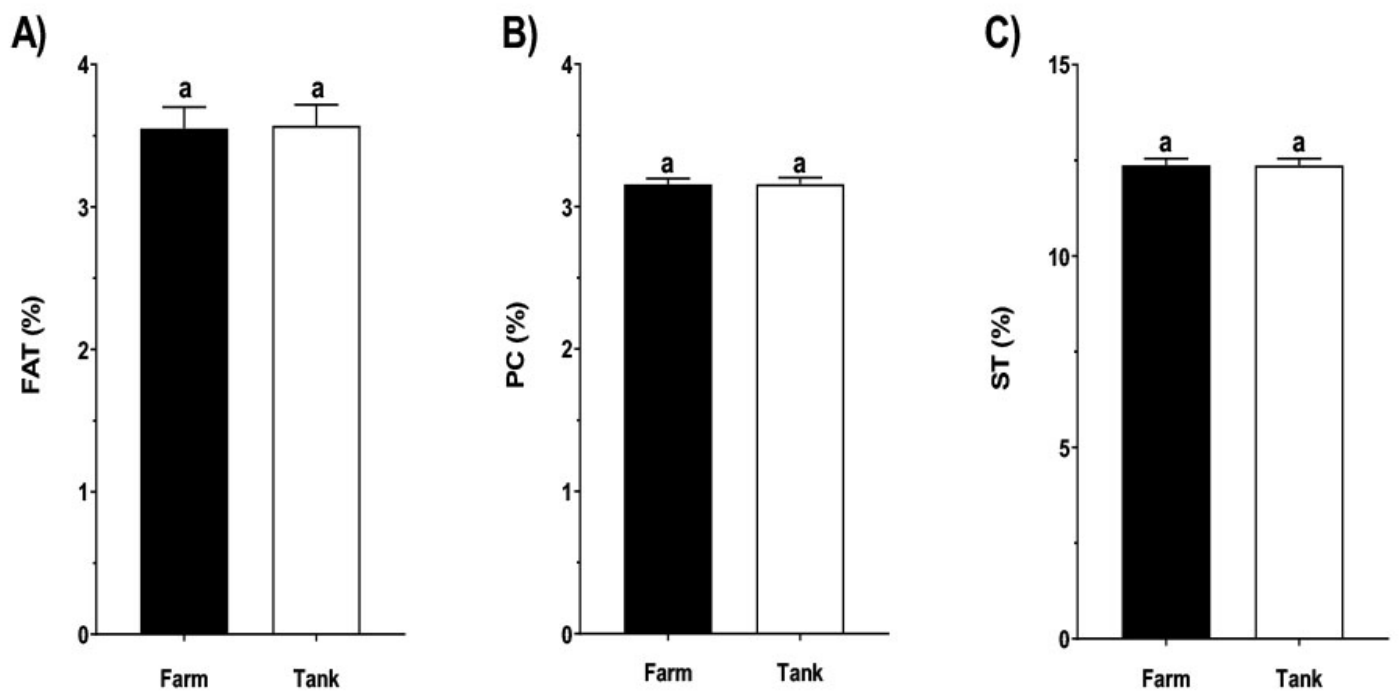

Figure 2. Mean \pm standard error of the mean (SEM) of A) fat (FAT), B) protein (PC), and C) total solids (TS) present in raw milk samples taken on the farm (black bars; $n=10$ ) and in the storage tank (white bars; $n=10$ ). Different letters (a-b) between bars indicate statistical differences between the groups ( $<<0.05)$. Nariño, Colombia. 2017.

Figura 2. Promedio \pm error estándar del promedio (EE) de A) Grasa, B) proteína y C) sólidos totales presentes en muestras de leche cruda tomadas en la finca (barras negras; $\mathrm{n}=10$ ) y en el tanque de acopio (barras blancas; $\mathrm{n}=10$ ). Barras con diferente letra $(\mathrm{a}-\mathrm{b}$ ) indican diferencia estadística $(\mathrm{p}<0,05)$ entre los grupos. Nariño, Colombia. 2017.

\section{Discussion}

The degree of milk contamination in many regions was associated with multiple factors, such as the hygiene of the utensils used, the milking area environment, the condition of the stables, and the environmental conditions. Accordingly, this study evaluated the microbiological and compositional quality of raw milk after milking in highland tropical areas of the department of Nariño, Colombia.

In these areas, as is the case of the current research, the environmental temperature affects the reduction in milk temperature. In the present study, was observed that, on typical environmental conditions of the highland tropics where the environmental temperature is less than $20^{\circ} \mathrm{C}$, the milk temperature shows a decrease of $7.4{ }^{\circ} \mathrm{C}$ from the end of the milking session up to its arrival to the cooling centers. To compare this effect, Vásquez et al. (2012) studied the temperature variation of raw milk in highland tropical areas compared to low tropical regions where temperatures are above $35^{\circ} \mathrm{C}$. The results of this study were similar to the present, finding that in the highland tropics, milk temperature decreased $6{ }^{\circ} \mathrm{C}$ (from 30 to $24{ }^{\circ} \mathrm{C}$ ) while it was kept in the herd until its subsequent collection. However, in the low tropical areas, a decrease of only $2{ }^{\circ} \mathrm{C}$ was observed (from 30 to $28^{\circ} \mathrm{C}$ ). 
Keeping the milk refrigerated after milking is a decisive factor to preserve milk quality; food standards recommend lowering temperature to at least $10{ }^{\circ} \mathrm{C}$ or $4{ }^{\circ} \mathrm{C}$ within two and four hours after milking, respectively (WHO and FAO, 2011; FAO, 2015).

Different refrigeration techniques have been proposed to solve the problem of refrigeration in small farms, including cooling using artisanal refrigerators, wells with the addition of cold water and farms with small cooling tanks (Rodrigues et al., 2016). In this study, was observed that milk was cooled from the end of the milking session until it reached the collection centers using the immersion system in water wells; this control measure achieved a reduction in the temperature of the milk of $3{ }^{\circ} \mathrm{C}$. Nevertheless, the microbiological quality of the milk was affected during transport, it could be associated, to first period of the year, that in this case, corresponded to the rainy season (Calderón et al., 2006). In this regard, the microorganism count was used as an acceptance determinant, and the microbiological quality of milk provides information on sanitary and hygienic conditions during milking, storage, and transport. The contamination in the farm can be explained by the bad cleaning and disinfection of utensils, teats or teat cups, and the hygiene of the personnel in charge of milking, among others (Hassan and Frank, 2011). The study revealed that the samples collected on the farm already had a considerable initial count of microorganisms, possibly attributed to the foci of contamination mentioned above. Nonetheless, the count of mesophilic microorganisms in the tank increased by $87 \%$. Similarly, microbiological variability has been related to the geographical location and seasonality (Elmoslemany et al., 2009).

In Mexico, the quality of the raw milk extracted from storage containers without refrigeration during several periods of the year (dry, rainy and winter seasons) exhibited significant differences in the microbiological counts obtained per season, being higher in the dry season (Álvarez-Fuentes et al., 2012). Likewise, in another work, microorganism counts were higher in the dry season compared to the winter season (1.0x108 vs. $\left.1.2 \times 1077 \mathrm{CFU} \mathrm{ml}^{-1}\right)$ (Martínez and Gomez, 2013). In another study that evaluated the quality of raw milk in two production systems in the Sabana of Bogota region, the results of the samples taken in the peak of the rainy season showed a mesophilic microorganism count higher than $1 \times 10^{6} \mathrm{CFU} \mathrm{ml}^{-1}$; on the contrary, in the minimum precipitation season, this value was 100 times lower (Calderón et al., 2006). Particularly for these two studies, the total coliform count exceeded the minimum acceptable standards in Colombia $\left(<300,000 \mathrm{CFU} \mathrm{ml}^{-1}\right)$, results that contrast with those obtained by the present research group in the tropical highlands of Nariño, with counts below the national regulations (i.e., 62,129 $\mathrm{CFU} \mathrm{ml^{-1 }}$ for mesophiles and $1,089 \mathrm{CFU} \mathrm{ml}^{-1}$ for coliforms).

In a field study conducted by Millogo et al. (2010) that compared the hygienic quality of raw milk along the dairy chain in the rainy and dry seasons with samples taken on farms, collection tanks, and local markets, the transport was mostly carried out using bicycles and motorcycles. The results showed an effect of the period of the year in the microorganism count, finding $10^{5} \mathrm{CFU} \mathrm{ml}{ }^{-1}$ in the rainy season and $10^{7} \mathrm{CFU} \mathrm{ml}{ }^{-1}$ in the dry period. These authors stated that the quality of the milk decreases along the dairy chain, a phenomenon attributed mainly to the absence of cooling systems. In the same line of research, Ruangwittayanusorn et al. (2016) inspected the quality of milk during transport from the farm to the production center and later to retailers in the summer, rainy and winter seasons. The findings showed that the average time for transport without using a cooling system from the farm to the production centers was $76.29 \mathrm{~min}$. The temperature of the milk decreased in all seasons, and the bacterial count during the summer was higher compared to the rainy and winter seasons $\left(5,812 \log 10 \mathrm{CFU} \mathrm{m}{ }^{-1}, 5,743 \log 10 \mathrm{CFU}\right.$ $\mathrm{ml}^{-1}$, and 5,713 $\log 10 \mathrm{CFU} \mathrm{ml}{ }^{-1}$, respectively). In a study where evaluated the microbiological quality of milk at different stages of the dairy value chain from the farm to the factory to identify contaminating microorganisms were evaluated, reported similar results; the findings related the loss of quality in the centers of production with an average coliform count of $7.1 \times 10^{\wedge} 4 \mathrm{CFU} \mathrm{m}^{-1}$ (Islam et al., 2018). Recommending greater attention in conservation during transport since at this stage, the proliferation of microorganisms can increase rapidly (Bonfoh et al., 2003).

The current study consolidated failures in milk management before and after milking, and the microbiological quality decreased during transport until it reached the cooling tanks; however, the bacterial counts were lower than 
those reported for low tropical areas. At this point, when there is no established cold chain, milk that remains at temperatures above $25{ }^{\circ} \mathrm{C}$ reaches an optimum $\mathrm{pH}$ for bacterial growth. Furthermore, when there is a high count of microorganisms in the initial stage, the generation and multiplication time occurs after 20 min (Barbaros, 1999), making it essential to apply adequate cooling parameters, decrease the transport time and improve the storage conditions for raw milk (Grimaud et al., 2007; Rodrigues et al., 2016).

The negative association between milk temperature with distance and transport time is considered a positive effect. It has been demonstrated that in regions with altitudes higher than 2,428 m.a.s.l., the risk of increasing CFU counts is five times lower, a phenomenon that would be explained by the decrease in milk temperature (Ruiz-Cortés et al. 2012).

The variation in milk composition is attributed to nutrition, management, animal genetics, and industrial technology; in this sense, the main changes impact fat on a larger scale (Walker et al., 2004). Under refrigerated conditions, increase in the storage time of milk has been associated with alterations in compositional quality of milk (Paludetti et al., 2018), however, in the present study, no differences in the compositional quality of milk were observed. Advances in this topic have been raised, and research on the effect of feeding on the compositional quality of bovine milk has focused on two areas as follows. i) assessing the effect of forage species in temperate zones, and ii) management alternatives on the concentration of fat and protein in specialized dairies (Auldist et al., 2000; Bargo et al., 2002; Mojica et al., 2009; César-Mendoza et al., 2011).

\section{Conclusions}

The microbiological quality of raw milk decreases due to the increase in the counts of aerobic mesophilic microorganisms and total coliforms obtained in the tank, attributed to poor refrigeration conditions. Likewise, the compositional quality of milk was not affected.

\section{Acknowledgments}

The authors want to thank Rocio Esperanza Patiño Burbano and the staff of the microbiology laboratory of Centro de Investigacion Tibaitata, Corporación Colombiana de Investigacion Agropecuaria (AGROSAVIA) (previously known as CORPOICA) for processing the samples. Likewise, to General Royalty System (SGR, by its Spanish acronym) and AGROSAVIA for financing this study.

\section{Cited literature}

Álvarez-Fuentes, G., J.G. Herrera-Haro, G.Alonso-Bastida, y A. Barreras-Serrano. 2012. Calidad de la leche cruda en unidades de producción familiar del sur de Ciudad de México. Arch. Med. Vet. 44:237-242. doi:10.4067/S0301-732X2012000300005

Auldist, M.J., N.A.Thomson, T.R. Mackle, J.P. Hill, and C.G. Prosser. 2000. Effects of pasture allowance on the yield and composition of milk from cows of different $\beta$-lactoglobulin phenotypes. J. Dairy Sci. 83:2069-2074. doi:10.3168/jds. S0022-0302(00)75088-0

Barbaros, O. 1999. Microbiology of liquid milk. In: R.K. Robinson et al., editors, Encyclopedia of food microbiology. Academic Press, Cambridge, MA, USA. p. 1436-1441.

Bargo, F., L.D. Muller, J.E. Delahoy, and T.W. Cassidy. 2002. Milk response to concentrate supplementation of high producing dairy cows grazing at two pasture allowances. J. Dairy Sci. 85:1777-1792. doi:10.3168/jds.S0022-0302(02)74252-5 
Bonfoh, B., A. Wasem, A.N. Traoré, A. Fané, H. Spillmann, C.F. Simbé, and J. Zinsstag. J. 2003. Microbiological quality of cows' milk taken at different intervals from the udder to the selling point in Bamako (Mali). Food Control 14:495-500. doi:10.1016/S0956-7135(02)00109-3

Butler, M., P. Herlihy, and P.B. Keenan. 2005. Integrating information technology and operational research in the management of milk collection. J. Food Eng. 70:341-349. doi:10.1016/j.jfoodeng.2004.02.046

Calderón, A., F. García, y G. Martínez. 2006. Indicadores de calidad de leches crudas en diferentes regiones de Colombia. Rev. MVZ 11:725-737. doi:10.21897/rmvz.457

Caramia, M., and F. Guerriero. 2009. A heuristic approach for the truck and trailer routing problem. J. Operational Res. Soc. 61:1168-1180. doi:10.1057/jors.2009.59

César-Mendoza, F., R. Martha-Pabón, y F. Juan-Carulla. 2011. Variaciones diarias de la oferta forrajera, efecto sobre la producción y calidad de la leche. Rev. MVZ 16:2721-2732.

Claassen, G.D.H., and T.H.B. Hendriks. 2007. An application of special ordered sets to a periodic milk collection problem. Eur. J. Operational Res. 180:754-769. doi:10.1016/j.ejor.2006.03.042

De-Silva, S.A.S.D., K.A.N.P. Kanugala, and N.S. Weerakkody. 2016. Microbiological quality of raw milk and effect on quality by implementing good management practices. Procedia Food Sci. 6:92-96. doi:10.1016/j.profoo.2016.02.019

Elmoslemany, A.M., G.P. Keefe, I.R. Dohoo, and R.T. Dingwell. 2009. Microbiological quality of bulk tank raw milk in prince edward Island dairy herds. J. Dairy Sci. 92:4239-4248. doi:10.3168/jds.2008-1751

FAO. 2015. Dairy products toolkit. FAO, Rome, ITA. http://www.fao.org/3/a-au164e.pdf (accessed Jan. 2016).

FAO. 2020. Dairy market review. FAO, Rome, ITA. http://www.fao.org/3/ca8341en/CA8341EN.pdf (accessed Jun. 2020)

FEDEGAN (Federación Colombiana de Ganaderos). 2019. Fondo nacional del ganado - Fondo de estabilización de precios. https://www.fedegan.org.co/estadisticas/produccion-0 (consultado 30 mar. 2020).

Fatouma-Mohamed-Latif, A., M.K. Somda, A.E. Fourreh, A.A. Okieh, C.N. Said, A. Mérito, and S. Yagi. 2017. Evaluation of microbiological quality of raw milk from farmers and dairy producers in six districts of Djibouti. J. Food: Microbiol. Safety Hygiene 02(03):1000124. doi:10.4172/2476-2059.1000124

Grimaud, B.P., M. Sserunjogi, and N. Grillet. 2007. An evaluation of milk quality in Uganda: Value chain assessment and recommendations. African J. Food Agric. Nutr. Dev. 7(5):1-16.

Hammond, S.T., J.H. Brown, J.R. Burger, T.P. Flanagan, T.S. Fristoe, N. Mercado-Silva, and J.G. Okie. 2015. Food spoilage, storage, and transport: Implications for a sustainable future. BioScience 65:758-768. doi:10.1093/biosci/biv081

Hassan, A.N., and J.F. Frank. 2011. Microorganisms associated with milk. In: J.W. Fuquay et al., editors, Encyclopedia of food microbiology, 2nd ed. Academic Press, Cambridge, MA, USA. p. 447-457. doi:10.1016/B978-0-12-374407-4.00309-5

Islam, M.A., S. Roy, A. Nabi, S. Solaiman, M. Rahman, M. Hug, A. Nurul, and N. Ahnmed. 2018. Microbiological quality assessment of milk at different stages of the dairy value chain in a developing country setting. Int. J. Food Microbiol. 278:11-19. doi:10.1016/j.ijfoodmicro.2018.04.028

Leal, B. 2017. Análisis de los factores internos en la producción de leche en trópico alto y bajo en Colombia. (Tesis de Licenciatura). Universidad de La Salle, Colombia.

Lopes, J.E., C.C. Lange, M.A.V. Brito, F. Santos, M.A. Silva, L. de-Moraes, and G. de-Souza. 2012. Relationship between total bacteria counts and somatic cell counts from mammary quarters infected by mastitis pathogens. Ciênc. Rural 42:691-696. doi:10.1590/S0103-84782012000400019 
Martínez, M., y C. Gómez. 2013. Calidad composicional e higiénica de la leche cruda recibida en industrias lácteas de Sucre, Colombia. Biotecnol. Sector Agropecu. Agroind. BSAA 11(2):93-100.

Masson, R., N. Lahrichi, and L. Rousseau. 2015. A two-stage solution method for the annual dairy transportation problem. Eur. J. Operational Res. 251:36-43. doi:10.1016/j.ejor.2015.10.058

Millogo, V., K. Svennersten-Sjaunja, G.A. Ouédraogo, and S. Agenäs. 2010. Raw milk hygiene at farms, processing units and local markets in Burkina Faso. Food Control 21:1070-1074. doi:10.1016/j.foodcont.2009.12.029

Ministerio de Agricultura. 2012. Resolución Número 000017 de 2012: Sistema de pago de la leche cruda al proveedor. Ministerio de Agricultura, COL. https:/www.minagricultura.gov.co/ministerio/direcciones/Documents/d.angie/Res\%20 \%20000017\%20de\%202012.pdf (consultado 8 abr. 2020).

Mojica, J.E., E. Castro, J. León, E.A. Cárdenas, M.L. Pabón, y J. Carulla. 2009. Efecto de la oferta de pasto kikuyo (Pennisetum clandestinum) sobre la producción y calidad composicional de la leche bovina. Livest. Res. Rural Dev. 21(1):21. http:// www.lrrd.org/lrrd21/1/moji21001.htm (consultado 4 ene. 2020).

Murphy, S.C., N.H. Martin, D.M. Barbano, and M. Wiedmann. 2016. Influence of raw milk quality on processed dairy products: How do raw milk quality test results relate to product quality and yield? J. Dairy Sci. 99:10128-10149. doi:10.3168/ jds.2016-11172

Paludetti, L.F., K. Jordan, A.L. Kelly, and D. Gleeson. 2018. Evaluating the effect of storage conditions on milk microbiological quality and composition. Irish J. Agric. Food Res. 57(1):52-62. doi:10.1515/IJAFR-2018-0006

Pantoja, J.C.F., D.J. Reinemann, and P.L. Ruegg. 2011. Factors associated with coliform count in unpasteurized bulk milk. J. Dairy Sci. 94:2680-2691. doi:10.3168/jds.2010-3721

Paszkiewicz, W., M.R. Tatara, P. Brodzki, and Z. Bełkot. 2015. Microbiological quality of milk sold directly from producers to consumers. J. Dairy Sci. 98:4294-4301. doi:10.3168/jds.2014-9187

Perko, B. 2011. Effect of prolonged storage on microbiological quality of raw milk. Microbiol. Quality Raw Milk 61(2):114-124.

Rodrigues, J.P.P., M.I. Marcondes, R.D.P. Lana, T.C. Da-Silva, and L.M. Rufino. 2016. Seasonal and handling effects on milk quality from Pires Rural Producers Association. Rev. Bras. Agropecu. Sust. 6:26-33. doi:10.21206/rbas.v6i1.305

Ruangwittayanusorn, K., D. Promket, and A. Chantiratikul. 2016. Monitoring the hygiene of raw milk from farms to milk retailers. Agric. Agric. Sci. Procedia 11:95-99. doi:10.1016/j.aaspro.2016.12.016

Ruiz-Cortés, T., S. Orozco, L. Rodríguez, J. Idárraga, y M. Olivera. 2012. Factores que afectan el recuento de Ufc en la leche en tanque en hatos lecheros del norte de Antioquia-Colombia. Rev. U.D.C.A Actual. Divul. Científ 15:147-155. doi:10.31910/rudca.v15.n1.2012.812

Secretaria de Agricultura y Medio Ambiente de Nariño. 2016. Consolidado Agropecuario Nariño 2014. Secretaria de Agricultura y Medio Ambiente de Nariño, COL.

Swai, E.S., and L. Schoonman. 2011. Microbial quality and associated health risks of raw milk marketed in the Tanga region of Tanzania. Asian Pacific. J. Trop. Biomed 1:217-222. doi:10.1016/S2221-1691(11)60030-0

Tolosa, T., J. Verbeke, S. Piepers, M. Tefera, Y. Getachew, K. Supré, and S. Devlieghers. 2016. Milk production, quality, and consumption in Jimma (Ethiopia): Facts and producers', retailers', and consumers' perspectives. Preven. Vet. Med. 124:914. doi:10.1016/j.prevetmed.2015.12.016

Vásquez, J.F., E.T. Loaiza, and M. Olivera. 2012. Calidad higiénica y sanitaria de leche cruda acopiada en diferentes regiones colombianas. Orinoquia 16(2):13-23. doi:10.22579/20112629.251 
Vithanage, N.R., M. Dissanayake, G. Bolge, E.A. Palombo, T.R. Yeager, and N. Datta. 2016. Biodiversity of culturable psychrotrophic microbiota in raw milk attributable to refrigeration conditions, seasonality and their spoilage potential. Int. Dairy J. 57:80-90. doi:10.1016/j.idairyj.2016.02.042

Walker, G.P., F.R. Dunshea, and P.T. Doyle. 2004. Effects of nutrition and management on the production and composition of milk fat and protein: A review. Austral. J. Agric. Res. 55:1009-1028. doi:10.1071/AR03173

WHO, and FAO. 2011. Codex alimentarus: Milk and milk products. $2^{\text {nd }}$ ed. WHO, and FAO, Rome, ITA. 